\title{
Antitumor effects of the combination of cholesterol reducing drugs
}

\author{
TADEUSZ ISSAT ${ }^{1,2}$, DOMINIKA NOWIS ${ }^{1}$, JACEK BIL $^{1}$, MAGDALENA WINIARSKA $^{1}$, \\ MAREK JAKOBISIAK ${ }^{1}$ and JAKUB GOLAB ${ }^{1,3}$ \\ ${ }^{1}$ Department of Immunology, Center of Biostructure Research, The Medical University of \\ Warsaw; ${ }^{2}$ Center for Reproductive Health, Institute of Mother and Child; ${ }^{3}$ Institute of \\ Physical Chemistry, Polish Academy of Sciences, Department 3, Warsaw, Poland
}

Received January 13, 2011; Accepted March 11, 2011

DOI: $10.3892 /$ or.2011.1261

\begin{abstract}
There are a number of potential mechanisms linking cholesterol homeostasis to processes that are tightly linked with carcinogenesis. Statins, which are inhibitors of 3-hydroxy3-methylglutaryl-coenzyme A reductase (HMG-CoAR), the rate-limiting enzyme in the mevalonic acid synthesis pathway, exert cytostatic and cytotoxic effects towards tumor cells. It seems that the cytostatic and cytotoxic effects of statins result from blocking protein prenylation, leading to inhibition of isoprenoid compound synthesis. Another compound which affects cholesterol metabolism is the plant alkaloid berberine. The aim of this study was to investigate potential antitumor effects of lovastatin combined with berberine. Combined with berberine, lovastatin appeared to exert potentiated cytostatic and/or cytotoxic effects against human MDA-MB231 breast cancer and murine Panc 02 pancreatic cancer cells. The obtained results indicated that the effect of berberine is not dependent on blocking protein prenylation in cells, and the toxic effect of lovastatin combined with berberine is reversed by addition of the substrates of this pathway to the level brought out by lovastatin alone. Lovastatin-berberine combination caused cell cycle inhibition in G1 phase after $48 \mathrm{~h}$ of incubation with drugs. In a Panc 02 pancreatic cancer model in mice, lovastatin-berberine combination slightly, but significantly, slowed down tumor growth. Taking into account the number of patients treated with the investigated drugs one may suppose that the described interactions may be of clinical value.
\end{abstract}

Correspondence to: Dr Tadeusz Issat, Department of Immunology, Center of Biostructure Research, The Medical University of Warsaw, Banacha 1a, F building, 02-097 Warsaw, Poland

E-mail: tadeki@interia.pl

Abbreviations: AP-1, activator protein 1; CDK, cyclin dependent kinase; COX-2, cyclooxygenase 2; FBS, fetal bovine serum; FPP, farnesyl pyrophosphate; GGPP, geranylgeranyl pyrophosphate; HMG-CoA, 3-hydroxy-3-methylglutaryl-coenzyme A; MA, mevalonic acid; MMP, matrix metalloproteinase

Key words: lovastatin, berberine, tumor, prenylation

\section{Introduction}

Cholesterol-reducing agents continuously attract enormous interest not only because of their beneficial cardiovascular effects, but also due to their influence on numerous physiological and pathophysiological processes (1-3). For example, statins, which are inhibitors of 3-hydroxy-3-methylglutaryl-coenzyme A (HMG-CoA) reductase target mevalonate pathway of cholesterol synthesis and impair production of isoprenoid compounds such as dolichol, ubiquinone and mevalonate-derived prenyl groups that are attached post-translationally to approximately $1 \%$ of all cellular proteins $(4,5)$. By affecting cellular cholesterol synthesis statins also influence the formation of lipid rafts which are water insoluble plasma membrane microdomains enriched in receptors and signal transduction molecules (6). The interference with so many critical biochemical processes makes their effects extremely pleiotropic. Although statins have so far been approved only for prophylaxis or treatment of cardiovascular diseases they also show some promising therapeutic activity in the management of Alzheimer's disease, osteoporosis, graft rejection and cancer $(7,8)$.

Despite alarming results of carcinogenicity studies in rodents (9-11) clinical observations did not show an overall increase in cancer incidence or mortality among statin users (12-14). In fact statins were rather associated with reductions in the incidence of colorectal, prostate and lung cancers as well as in melanoma (15-17). Suggestion that statins could increase the risk of breast cancer development was subsequently called into question by other studies $(2,12,13,18)$. Despite promising preclinical activity of statins in numerous in vitro and in vivo rodent models of transplantable tumors none of the clinical studies showed significant antitumor activity of these drugs. It seems therefore that statins will not become effective antitumor agents used in monotherapy. Nonetheless, these drugs are among the most frequently prescribed therapeutics and are taken on a regular basis especially by elderly people. Therefore, any combinations with other drugs that would show potentiated antitumor activity by addition of statins might become of clinical significance.

The aim of this study was to evaluate antitumor effect of the combination of lovastatin and berberine, a naturally occurring isoquinoline alkaloid, produced by a number of medicinal 
plants. Berberis (Berberis vulgaris from Berberidaceae family) is a plant growing in Europe and Asia and has been used for a long time in folk medicine. Its therapeutic value is attributed to the root, bark, leaves and fruits. Research carried out on the composition of Berberis extract enabled to isolate such compounds as berberine, berbamine or palmatine (19). Berberine seems to be the most potent of these alkaloids, responsible for the majority of pleiotropic effects. However, the remaining compounds may also play a certain role (20). Previous studies revealed that berberine not only decreases cholesterol concentration but also displays cytostatic and/or cytotoxic effects against a number of cancer cell lines (21-24).

\section{Materials and methods}

Reagents. Lovastatin in the inactive lactone form was obtained from Merck, Sharp and Dohme Research Laboratories (Rahway, NJ). It was converted to the active form by dissolving in ethanol, heating at $50^{\circ} \mathrm{C}$ in $0.1 \mathrm{~N} \mathrm{NaOH}$, and neutralizing with $\mathrm{HCl}$. Distilled water was added to a final concentration of $10 \mathrm{mM}$. This stock solution was stored frozen $\left(-80^{\circ} \mathrm{C}\right)$. Berberine hydrochloride, farnesyl pyrophosphate (FPP), geranylgeranyl pyrophosphate (GGPP) and mevalonic acid (MA) were purchased from Sigma-Aldrich (St. Louis, MO).

Tumors. MDA-MB231 cells were obtained from ATCC (American Type Culture Collection, Rockville, MD, USA) and Panc 02, a murine pancreatic carcinoma cells were kindly provided by Carsten Ziske (Rheinische Friedrich-WilhelmsUniversität, Bonn, Germany). Cells were maintained in DMEM or RPMI-1640 medium (Invitrogen, Co., Paisley, UK), supplemented with $10 \%$ heat-inactivated fetal bovine serum (FBS), antibiotics, 2-mercaptoethanol $(50 \mu \mathrm{M})$ and L-glutamine (2 $\mathrm{mM}$ ) (all from Invitrogen), hereafter referred to as culture medium. Cells were cultured in $75 \mathrm{~cm}^{2}$ tissue flasks (Sarstedt, Nümbrecht, Germany) at $37^{\circ} \mathrm{C}$ in a fully humidified atmosphere of $5 \% \mathrm{CO}_{2}$, and were passaged every 3-4 days after short trypsinization with trypsin/EDTA (Invitrogen). Tumor cell viability estimated by trypan blue staining ranged between 95 and $97 \%$.

Mice. C57BL/6 mice, 8-12 weeks of age were used in the experiments. Breeding pairs were obtained from the Animal House of the Medical Research Centre, Polish Academy of Sciences. Mice were kept in conventional conditions with full access to food and water during experiments. The animal studies were performed in accordance with the guidelines approved by the Ethics Committee of the Medical University of Warsaw.

Tumor treatment and monitoring. For in vivo experiments exponentially growing Panc 02 cells were harvested from culture flasks and washed twice in cold PBS (Polfa, Poland). Cells were then washed twice and resuspended in PBS at a concentration of $50 \times 10^{6}$ cells $/ \mathrm{ml}$ and injected $\left(0.1 \times 10^{6}\right)$ into the footpads of the right hind limbs of C57BL/6 mice. Lovastatin was administered intraperitoneally (i.p.) at a dose of $30 \mathrm{mg} /$ $\mathrm{kg}$ daily starting from day 7 after inoculation of tumor cells for 14 consecutive days. Control mice received equal volume of $20 \%$ ethanol. Berberine was administrated per os at a dose of $100 \mathrm{mg} / \mathrm{kg}$ in the same schedule as lovastatin. Local tumor growth was determined as described (25), by the formula: tumor volume $\left(\mathrm{mm}^{3}\right)=$ (longer diameter) $\mathrm{x}$ (shorter diameter $)^{2}$. Relative tumor volume was calculated as: relative tumor volume $=[$ (tumor volume $) /($ initial volume $)] \times 100 \%$.

Cytostatic/cytotoxic assay. The cytostatic/cytotoxic effects were measured using crystal violet staining. Briefly, MDA-MB231 or Panc 02, cells were dispensed into a 96-well plate (Sarstedt) at the concentration of $5 \times 10^{3}$ cells per dish/100 $\mu \mathrm{l}$, and allowed to attach overnight. The following day all reagents were added. Then, $48 \mathrm{~h}$ after incubation with reagents (berberine, lovastatin, mevalonic acid, FPP, GGPP) the cells were rinsed with PBS and stained with $0.5 \%$ crystal violet in $30 \%$ ethanol for $10 \mathrm{~min}$ at room temperature. Plates were washed four times with tap water and the cells were lysed with $1 \%$ SDS solution. Absorbance was measured at $595 \mathrm{~nm}$ using an enzyme-linked immunosorbent assay reader (SLT Labinstrument $\mathrm{GmbH}$, Salzburg, Austria). Cytotoxicity was expressed as relative viability of tumor cells (\% of control cultures incubated with medium only) and was calculated as follows: relative viability $=\left(A_{e}-A_{b}\right) \times 100 /\left(A_{c}-A_{b}\right)$, where $A_{b}$ is the background absorbance, $A_{e}$ is experimental absorbance, and $A_{c}$ is the absorbance of untreated controls.

Cell cycle analysis. For the cell cycle analysis $1 \times 10^{6}$ of tumor cells (Panc 02, MDA-MB231) were scraped off the Petri dishes (Sarstedt) in chilled PBS after incubation with lovastatin (0.5 $\mu \mathrm{M}$ for MDA-MB231 and $0.25 \mu \mathrm{M}$ for Panc 02), berberine (5 and $10 \mu \mathrm{M}$ ) or both for $48 \mathrm{~h}$. Tumor cells were then washed twice and fixed in $70 \%$ ethanol in PBS. Analysis of the cell cycle was performed with propidium iodide staining (Roche, Indianapolis, IN, USA) according to the manufacturer's protocols and analyzed using Ventage FACS (Beckton-Dickinson, Franklin Lakes, NJ, USA).

Statistical analysis. Data were calculated using Microsoft $\mathrm{t}^{\mathrm{TM}}$ Excel 2007. Differences in in vitro cytotoxicity assays and tumor volume were analyzed for significance by Student's $\mathrm{t}$-test. Significance was defined as a two-sided $\mathrm{P}<0.05$.

The nature of the interaction observed between lovastatin and berberine was analyzed using the Calcusyn software (Biosoft, Cambridge, UK) which uses the combination index (CI) method of Chou and Talalay, based on multiple drug effect equation (26). The constant ratio combination design was applied to assess the effect of both drugs in combination, in which dose-response curves were determined. The advantage of this method is the automatic construction of a fraction affected-CI table, graph and calculation of dose reduction indices by the software. CI's $<1$ indicate greater than additive effects (synergism: the smaller the value, the greater the degree of synergy), CI's equal to 1 indicate additivity, and CI's $>1$ indicate antagonism. The dose reduction index defines the extent of drug dose reduction possible in combination for a given degree of effect as compared with the dose of each drug alone.

\section{Results}

Berberine and lovastatin exert synergistic cytostatic/cytotoxic effects against tumor cells in vitro. Cytostatic/cytotoxic effects 
A

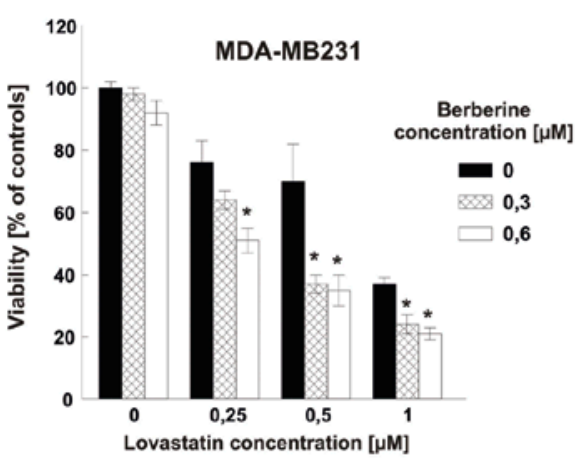

C

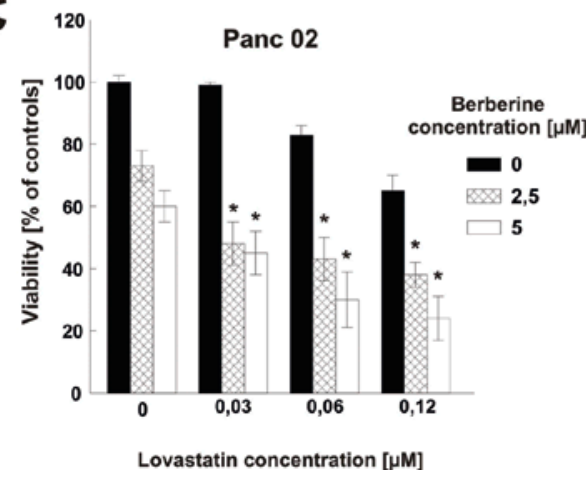

B

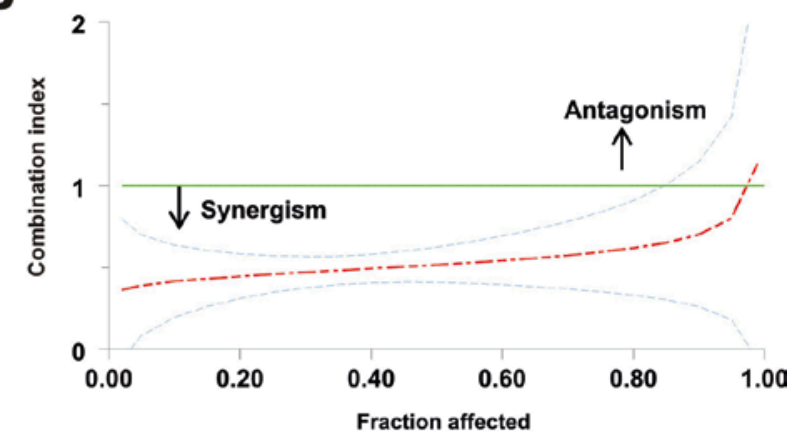

D

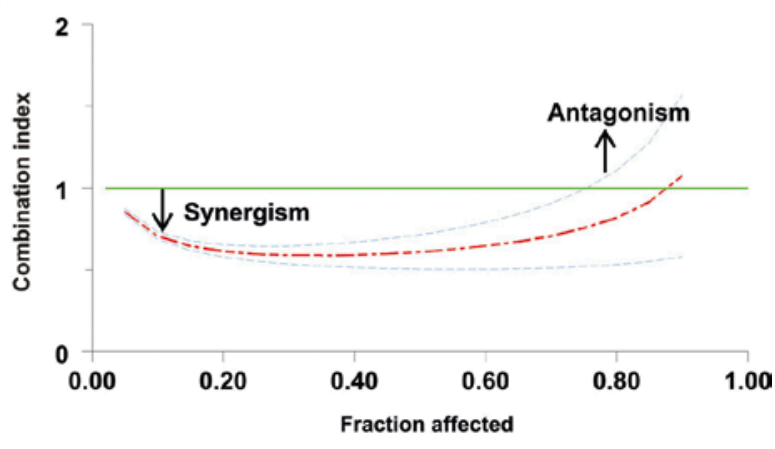

Figure 1. Cytostatic/cytotoxic effects of the combination treatment with lovastatin and berberine in MDA-MB231 and Panc 02 cells. MDA-MB231 cells (A and B) and Panc 02 cells (C and D) were incubated with lovastatin and/or berberine for $48 \mathrm{~h}$ at indicated concentrations. The cytostatic and/or cytotoxic effects of the treatment on the tumor cells were measured with crystal violet staining. The results of the Chow and Talalay analyses of the combination indices (CI) (B and D) are presented as a function of inhibition of cell growth in cells exposed to lovastatin and berberine for $48 \mathrm{~h}$ (solid red lines) \pm SD (thin hyphenated line). The straight line at $\mathrm{CI}=1$ represents the additive effects of both drugs. ${ }^{*} \mathrm{P}<0.05$ (Student's t-test) as compared with controls and single agent-treated cells.

exerted by berberine and lovastatin as well as by their combination were investigated in human breast (MDA-MB231) and murine pancreatic (Panc 02) cancer cell lines using crystal violet staining. Both berberine and lovastatin exerted a dose-dependent growth inhibition against tumor cells. The combination of berberine and lovastatin exerted potentiated cytostatic/cytotoxic effects against both investigated tumor cell lines (Fig. 1A and $\mathrm{C}$ ). The resulting data were elaborated with a dedicated Calcusyn software to verify potential synergistic interactions between the investigated agents using a Chow and Talalay calculations. In this mathematical model, synergism can be defined when the combination index (CI) is below 1.0 (when $\mathrm{CI}$ is below 0.5 the synergism is defined as very strong). We have found that the combination of berberine and lovastatin was highly synergistic when both drugs were used at equipotent concentrations against MDA-MB231 cells (Fig. 1B). A synergistic interaction was also noted for Panc 02 cells (Fig. 1D).

The combination of berberine and lovastatin induces cell cycle arrest and apoptosis. We selected such concentrations of berberine and lovastatin that were highly synergistic at Calcusyn calculations to evaluate the influence of the combination on the cell cycle progression and apoptosis induction in MDA-MB231 and Panc 02 cells (Table I). Lovastatin used at 0.5 and $0.25 \mu \mathrm{M}$ concentration respectively, for 48-h incubation induced G1 arrest in MDA-MB231 cells only. Berberine at the concentration of 5 and $10 \mu \mathrm{M}$ did not significantly influence cell cycle distribution or apoptosis induction in investigated tumor cells. However, the combination treatment strongly increased the percentage of MDA-MB231 cells in subG1 fraction (from maximal $11.42 \%$ in single-agent treated cells to $55.29 \%$ in the combination group) (Table I). In Panc 02 cells the combination of berberine and lovastatin resulted in almost 2-fold increase in the sub-G1 phase (from $6.99 \%$ in lovastatin-treated cells to $12.80 \%$ in the combination group) and significantly increased the percentage of cells in G1 phase of the cell cycle (Table I).

The cytostatic/cytotoxic effects of the combination of berberine and lovastatin do not result from potentiated inhibition of isoprenoid compound synthesis. By inhibiting HMG-CoA reductase, statins decrease synthesis of mevalonic acid-derived isoprenoid compounds thereby influencing post-translational modification of numerous proteins, including Ras and Rho family members. Incubation of Panc 02 and MDA-MB231 cells with mevalonic acid, farnesyl- or geranylgeranyl pyrophosphate abrogated cytostatic/cytotoxic effects of lovastatin (Fig. 2). Accordingly to our previous finding that berberine exerts cytostatic/cytotoxic effects independent of mevalonate pathway (27) we observed that mevalonate, FPP or GGPP do not influence the growth inhibitory effects of berberine (Fig. 2). The products of mevalonate pathway diminished cytostatic/cytotoxic effects of the combination treatment but only to the levels of berberine action indicating that berberine potentiates cytostatic/cytotoxic effects of 
Table I. The influence of lovastatin, berberine and drug combination on MDA-MB231 or Panc 02 cell cycle progression and apoptosis induction.

\begin{tabular}{|c|c|c|c|c|c|c|}
\hline & Controls & $\begin{array}{l}\text { Lovastatin } \\
(0.5 \mu \mathrm{M})\end{array}$ & $\begin{array}{c}\text { Berberine } \\
(5 \mu \mathrm{M})\end{array}$ & $\begin{array}{c}\text { Lovastatin } \\
(0.25 \mu \mathrm{M})\end{array}$ & $\begin{array}{c}\text { Berberine } \\
(10 \mu \mathrm{M})\end{array}$ & Lova+Ber \\
\hline \multicolumn{7}{|l|}{ MDA-MB231 } \\
\hline Sub G1 (\%) & 8.22 & 2.76 & 11.42 & & & 55.29 \\
\hline G1 (\%) & 45.05 & 67.19 & 44.19 & & & 30.10 \\
\hline $\mathrm{S}(\%)$ & 30.20 & 14.85 & 25.89 & & & 8.58 \\
\hline $\mathrm{G} 2 / \mathrm{M}(\%)$ & 16.52 & 15.19 & 18.49 & & & 6.02 \\
\hline \multicolumn{7}{|l|}{ Panc 02} \\
\hline Sub G1 (\%) & 2.02 & & & 6.99 & 5.31 & 12.80 \\
\hline $\mathrm{G} 1(\%)$ & 63.34 & & & 60.67 & 62.17 & 75.75 \\
\hline S (\%) & 20.05 & & & 17.93 & 16.41 & 2.93 \\
\hline $\mathrm{G} 2 / \mathrm{M}(\%)$ & 14.57 & & & 14.39 & 16.09 & 8.50 \\
\hline
\end{tabular}

Cells were grown in Petri dishes for $24 \mathrm{~h}$ before addition of lovastatin and/or berberine for $48 \mathrm{~h}$. Cell cycle analysis was performed by flow cytometric analysis using ethanol-fixed, propidium iodide-stained cells.
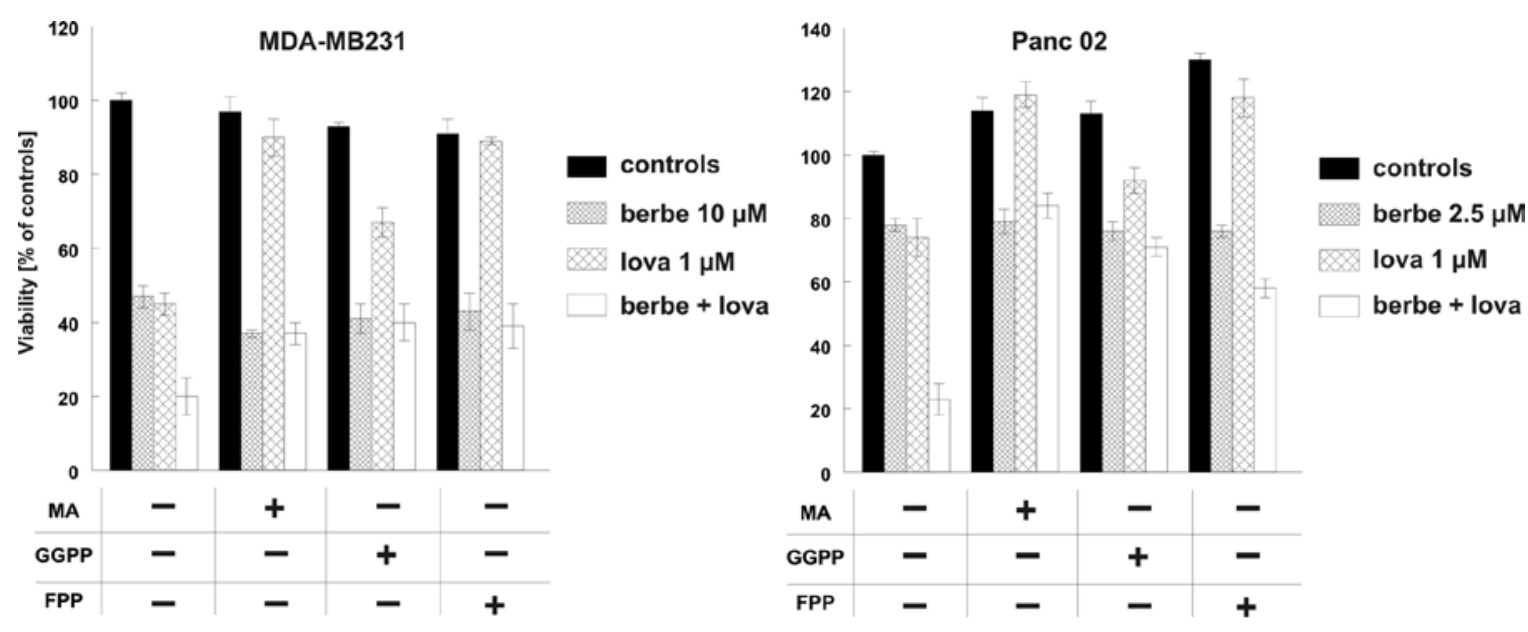

Figure 2. Cytostatic/cytotoxic effects of lovastatin and berberine do not depend on inhibition of protein prenylation. MDA-MB231 and Panc 02 and cells were dispensed into a 96-well flat-bottomed microtiter plate at a concentration of $5 \times 10^{3}$ cells/100 $\mu 1 /$ well. Cells were incubated with dilutions of lovastatin and/or berberine with or without the following precursors of the prenyl groups: $200 \mu \mathrm{M}$ mevalonic acid (MA), $10 \mu \mathrm{M}$ farnesylpyrophosphate (FPP) or $10 \mu \mathrm{M}$ geranylgeranyl pyrophosphate (GGPP). After $48 \mathrm{~h}$ of incubation with drugs the cytostatic/cytotoxic effects were measured using crystal violet staining and are expressed as relative viability (as compared with controls) \pm SD.

lovastatin independent of inhibition of cholesterol synthesis pathway (Fig. 2).

To further verify the role of protein prenylation in the cytostatic/cytotoxic effects of combination with berberine, we combined the latter with an inhibitor of protein farnesylation (FTI) or geranylgeranylation (GGTI). Inhibition of farnesyltransferase or geranylgeranyltransferase was ineffective in potentiating cytostatic/cytotoxic effects of berberine against MDA-MB231 (Fig. 3A and B) and Panc 02 cells cells (Fig. 3C and D).

The combination of berberine and lovastatin exerts potentiated antitumor effects in vivo. Next, antitumor activity of the combination treatment was evaluated in vivo in a murine model of syngeneic pancreatic carcinoma (Panc 02) growing in C57/B16 mice. Treatment with berberine and/or lovastatin was started 7 days following inoculation of tumor cells. Berberine and lovastatin were used at 100 and $30 \mathrm{mg} / \mathrm{kg}$ doses, respectively on days 7-21. Although both drugs only slightly inhibited tumor growth when given alone, their concomitant administration resulted in a significant retardation of tumor growth as compared to all other groups $(\mathrm{P}<0.05$ on days 15,19 and 35) (Fig. 4).

\section{Discussion}

Molecular mechanisms underlying antitumor potential of statins seem to depend on inhibition of Ras and Rho protein 

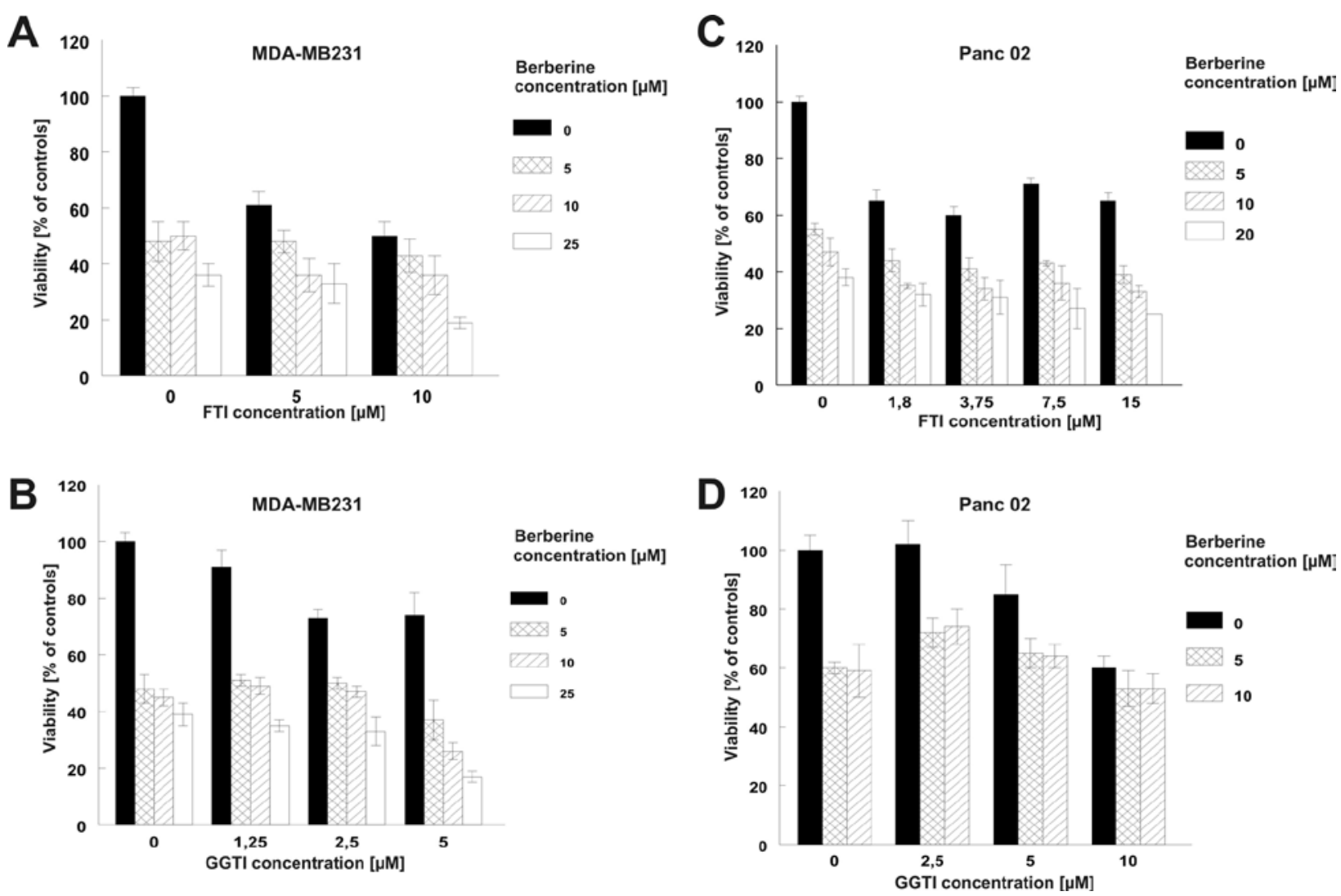

Figure 3. Cytostatic/cytotoxic effects of the combinations of berberine with geranylgeranyl transferase (GGTI) or farnesyltransferase (FTI) inhibitors. MDA-MB231 and Panc 02 and cells were dispensed into a 96-well flat-bottomed microtiter plate at a concentration of 5x10 cells/100 $\mu 1 /$ well. Cells were incubated with dilutions of berberine and/or berberine with or without geranylgeranyl transferase (GGTI) or farnesyltransferase (FTI) inhibitors. After $48 \mathrm{~h}$ of incubation with drugs the cytostatic/cytotoxic effects were measured using crystal violet staining and are expressed as relative viability (as compared with controls) $\pm \mathrm{SD}$.

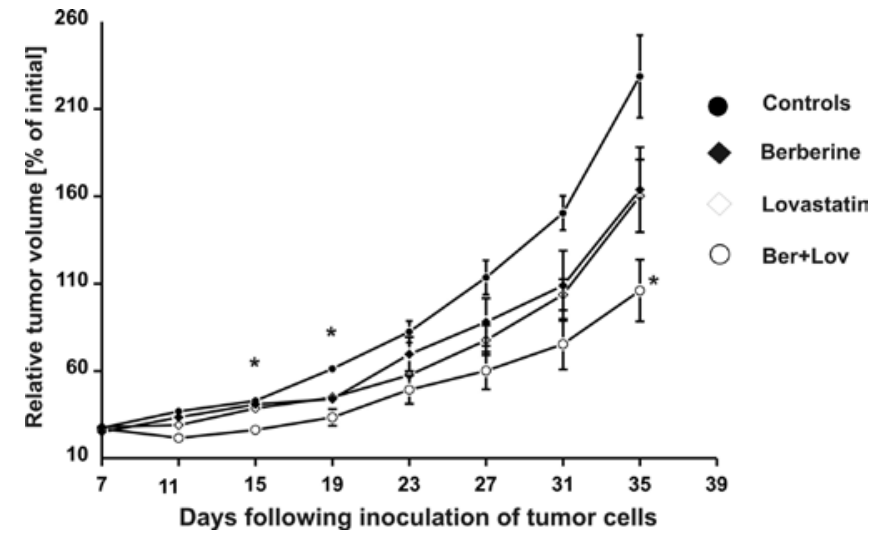

Figure 4. Antitumor effect of the combined treatment with lovastatin and/ or berberine in Panc 02-bearing mice. C57BL/6 mice were inoculated with $2 \times 10^{5}$ Panc 02 cells. Administration of lovastatin $(30 \mathrm{mg} / \mathrm{kg})$ was started on day 7 and continued for 2 consecutive weeks. Berberine was administered per os at a dose of $100 \mathrm{mg} / \mathrm{kg}$ on days 7-21 following inoculation of tumor cells. ${ }^{*} \mathrm{P}<0.05$ (Student's t-test) in comparison with all other groups.

prenylation which results from blocking mevalonic acid metabolism. Moreover, statins induce cancer cell apoptosis and this effect was observed in many cancer cell lines (28-30). HMG-CoA reductase inhibitors affect cell cycle causing inhibition in G1 phase of cell cycle $(9,28,31,32)$. Some researches show that this effect may depend on inhibition of Ras farnesylation, but also on inhibition of geranylgeranylation of other proteins, including Rho family members (33-35). Incubation of tumor cells with statins leads to increased levels of p21Cip1/ Waf1 and p27Kip1 proteins, which are inhibitors of cyclindependent kinases, CDK $(36,37)$. Statins can also decrease the expression and/or activity of cyclins: A, D1, D3 and E, as well as cyclin-dependent kinases: CDK4 and CDK6 (38-40).

Many studies revealed that statins potentiate cytostatic and/or cytotoxic effects in vitro or antitumor effect in experimental tumor models of many chemotherapeutics, including anthracyclines $(30,41-43)$, cisplatin (44-46) or 5-fluorouracil $(29,47)$.

Increasing evidence indicates that berberine, an ancient herbal medicine that decreases cholesterol concentration in humans, exerts potential cytostatic/cytotoxic effects, observed in a number of cancer cell lines (48). It was shown that incubation of tumor cells with berberine leads to cell cycle arrest in G1 phase, followed by apoptosis induction (49). Berberine decreases expression of cyclins D and C, as well as CDK2 and 6. Like statins it is also capable of increasing expression of cyclin-dependent kinase inhibitors (p21 $1^{\text {Cip1/Waf-1 }}$ and p27 ${ }^{\mathrm{Kip} 1}$ ). Berberine can also induce apoptosis, which results from a higher $\mathrm{Bax} / \mathrm{Bcl} 2$ ratio (50). Apart from the influence on Bax expression it was also observed that berberine enhances expression of other pro-apoptic proteins 
such as ATF3 or NAG-1 (50). Berberine-induced tumor cell apoptosis may also result from oxidative stress induction, which leads to cytochrome c release, caspase activation and cell apoptosis (51). Some studies suggest that this alkaloid can also increase p53 expression in cancer cells $(52,53)$, but the mechanism of this effect remains unclear. Berberine also displays anti-angiogenic potential (54), and reduces cancer cells invasiveness and their metastatic potential due to inhibition of metalloproteinases (MMP-1, -2, -9) secretion from tumor cells (55-57), and induction of the synthesis of TIMP-2 (tissue inhibitor of metalloproteinase-2 (58). In an animal model berberine decreased the number of LLC lung cancer metastases to the local lymph nodes, which correlated with the inhibition of urokinase plasminogen activator (u-PA) (59), whereas by influencing bone marrow stromal cells berberine reduced the production of stromal-cell derived factor-1 (SDF-1), a chemokine ligand for CXCR4 receptor, regulating migration of leukemic cells (60).

The aim of this study was to verify whether lovastatin potentiates cytostatic/cytotoxic effects of berberine against tumor cells. Combined with berberine lovastatin exerted a synergistic cytostatic and/or cytotoxic effects against MDA-MB231 and Panc 02 tumor cell lines (Fig. 1). It was observed that the effect of berberine does not depend on blocking of the mevalonic acid metabolism, and cytotoxic effect of lovastatin combined with berberine is reversed by addition of the substrates of this pathway to the level brought out by lovastatin only (Fig. 2). Although contrary to previous studies that showed G1 cell cycle arrest in cells incubated with berberine alone (49) the combination of lovastatin and berberine produced G1 cell cycle arrest within $48 \mathrm{~h}$ followed by the transition of G1-arrested cells into sub-G1 fraction (Table I). Combination of lovastatin and berberine exhibited antitumor effects in vivo, despite negligible effects observed in single agent-treated mice (Fig. 4).

Based on these observations it can be speculated that the synergistic interaction of these drugs results from geranylgeranylation inhibition by statins and certain undefined mechanism brought out by berberine, independent of blocking mevalonic acid metabolism. The use of statins combined with berberine was previously tested in humans. Simvastatin combined with berberine caused increased expression of receptors for LDL and lower LDL concentration in serum of the patients. Such a combination did not exert any side effect in the study group which points to high safety profile of this drug combination (61). In numerous studies carried out hitherto statins showed a marginal or no antitumor effects both in animals and in humans $(17,62,63)$. Therefore, it seems that statins are unlikely to be used purposefully in oncology as anticancer therapeutics in monotherapy. However, statins have a well-established position in therapy of human diseases, are in a regular use by millions of people, and the number of indications for their use is still increasing. The people who take stains are mainly elderly individuals who have higher cancer risk due to their advanced age. Therefore, it seems important to search for therapeutic combinations in which statins could potentiate the effects of acknowledged therapeutics or novel compounds displaying antitumor effects. Patients with tumors who undergo chemotherapy frequently experience local and systemic toxic effects. Statins and berberine may not only act as therapeutics capable of potentiating antitumor effects of other drugs, but may also selectively neutralize some of their undesirable effects (41). On the other hand statins might occasionally inhibit or even neutralize beneficial antitumor effects of established antitumor therapeutics (64).

\section{Acknowledgements}

The research was supported by: Ministry of Science and Higher education grant N N405 302836 (M.J.); European Regional Development Fund through Innovative Economy grant POIG.01.01.02-00-008/08 (J.G.). J.G. and M.W. are members of TEAM Programme co-financed by the Foundation for Polish Science and the EU European Regional Development Fund, and J.G. is a recipient of the Mistrz Award from the Foundation for Polish Science. J.B. is a recipient of the START Award the Foundation for Polish Science.

\section{References}

1. Pedersen TR, Kjekshus J, Berg K, Haghfelt T, Faergeman O, Faergeman G, Pyörälä K, Miettinen T, Wilhelmsen L, Olsson AG and Wedel H; Scandinavian Simvastatin Survival Study Group: Randomised trial of cholesterol lowering in 4444 patients with coronary heart disease: the Scandinavian Simvastatin Survival Study (4S). Atheroscler Suppl 5: 81-87, 2004.

2. Sacks FM, Pfeffer MA, Moye LA, Rouleau JL, Rutherford JD, Cole TG, Brown L, Warnica JW, Arnold JM, Wun CC, Davis BR and Braunwald $\mathrm{E}$ : The effect of pravastatin on coronary events after myocardial infarction in patients with average cholesterol levels. Cholesterol and Recurrent Events Trial investigators. N Engl J Med 335: 1001-1009, 1996.

3. Velasco JA: After 4S, CARE and LIPID - is evidence-based medicine being practised? Atherosclerosis 9: 147, 1999.

4. Kusama T, Mukai M, Iwasaki T, Tatsuta M, Matsumoto Y, Akedo $\mathrm{H}$, Inoue $\mathrm{M}$ and Nakamura H: 3-Hydroxy-3-methylglutarylcoenzyme a reductase inhibitors reduce human pancreatic cancer cell invasion and metastasis. Gastroenterology 122: 308-317, 2002.

5. Denoyelle C, Vasse M, Körner M, Mishal Z, Ganné F, Vannier JP, Soria J and Soria C: Cerivastatin, an inhibitor of HMG-CoA reductase, inhibits the signaling pathways involved in the invasiveness and metastatic properties of highly invasive breast cancer cell lines: an in vitro study. Carcinogenesis 22: 1139-1148, 2001.

6. Williams TM and Lisanti MP: Caveolin-1 in oncogenic transformation, cancer, and metastasis. Am J Physiol Cell Physiol 288: C494-C506, 2005.

7. Nissen SE, Tuzcu EM, Schoenhagen P, Brown BG, Ganz P, Vogel RA, Crowe T, Howard G, Cooper CJ, Brodie B, Grines CL, DeMaria AN and REVERSAL Investigators: Effect of intensive compared with moderate lipid-lowering therapy on progression of coronary atherosclerosis: a randomized controlled trial. JAMA 291: 1071-1080, 2004.

8. Waters D, Schwartz GG and Olsson AG: The myocardial ischemia reduction with acute cholesterol lowering (MIRACL) trial: a new frontier for statins? Curr Control Trials Cardiovasc Med 2: 111-114, 2001.

9. Lamprecht J, Wójcik C, Jakóbisiak M, Stoehr M, Schrorter D and Paweletz N: Lovastatin induces mitotic abnormalities in various cell lines. Cell Biol Int 23: 51-60, 1999.

10. MacDonald JS, Gerson RJ, Kornbrust DJ, Kloss MW, Prahalada S, Berry PH, Alberts AW and Bokelman DL: Preclinical evaluation of lovastatin. Am J Cardiol 62: J16-J27, 1988.

11. Newman TB and Hulley SB: Carcinogenicity of lipid-lowering drugs. JAMA 275: 55-60, 1996.

12. Downs JR, Clearfield M, Weis S, Whitney E, Shapiro DR, Beere PA, Langendorfer A, Stein EA, Kruyer W and Gotto AM Jr: Primary prevention of acute coronary events with lovastatin in men and women with average cholesterol levels: results of AFCAPS/ TexCAPS. Air Force/Texas Coronary Atherosclerosis Prevention Study. JAMA 279: 1615-1622, 1998. 
13. Reid IR, Hague W, Emberson J, Baker J, Tonkin A, Hunt D, MacMahon S and Sharpe N: Effect of pravastatin on frequency of fracture in the LIPID study: secondary analysis of a randomised controlled trial. Long-term Intervention with Pravastatin in Ischaemic Disease. Lancet 357: 509-512, 2001.

14. Kaye JA, Meier CR, Walker AM and Jick H: Statin use, hyperlipidaemia, and the risk of breast cancer. Br J Cancer 86: $1436-1439,2002$

15. Poynter JN, Gruber SB, Higgins PD, Almog R, Bonner JD, Rennert HS, Low M, Greenson JK and Rennert G: Statins and the risk of colorectal cancer. N Engl J Med 352: 2184-2192, 2005.

16. Clearfield M, Downs JR, Weis S, Whitney EJ, Kruyer W, Shapiro DR, Stein EA, Langendorfer A, Beere PA and Gotto AM: Air Force/Texas Coronary Atherosclerosis Prevention Study (AFCAPS/TexCAPS): efficacy and tolerability of long-term treatment with lovastatin in women. J Womens Health Gend Based Med 10: 971-981, 2001.

17. Graaf MR, Beiderbeck AB, Egberts AC, Richel DJ and Guchelaar HJ: The risk of cancer in users of statins. J Clin Oncol 22: 2388-2394, 2004

18. Coogan PF, Rosenberg L, Palmer JR, Strom BL, Zauber AG and Shapiro S: Statin use and the risk of breast and prostate cancer. Epidemiology 13: 262-267, 2002.

19. Ivanovska N and Philipov S: Study on the anti-inflammatory action of Berberis vulgaris root extract, alkaloid fractions and pure alkaloids. Int J Immunopharmacol 18: 553-561, 1996.

20. Yeşilada E and Küpeli E: Berberis crataegina root exhibits potent anti-inflammatory, analgesic and febrifuge effects in mice and rats. J Ethnopharmacol 79: 237-248, 2002.

21. Kong W, Wei J, Abidi P, Lin M, Inaba S, Li C, Wang Y, Wang Z, Si S, Pan H, Wang S, Wu J, Wang Y, Li Z, Liu J and Jiang JD: Berberine is a novel cholesterol-lowering drug working through a unique mechanism distinct from statins. Nat Med 10: 1344-1351, 2004.

22. Youn MJ, So HS, Cho HJ, Kim HJ, Kim Y, Lee JH, Sohn JS, Kim YK, Chung SY and Park R: Berberine, a natural product, combined with cisplatin enhanced apoptosis through a mitochondria/caspase-mediated pathway in HeLa cells. Biol Pharm Bull 31: 789-795, 2008

23. Lin HL, Liu TY, Wu CW and Chi CW: Berberine modulates expression of mdrl gene product and the responses of digestive track cancer cells to Paclitaxel. Br J Cancer 81: 416-422, 1999.

24. Wang XN, Han X, Xu LN, Yin LH, Xu YW, Qi Y and Peng JY: Enhancement of apoptosis of human hepatocellular carcinoma SMMC-7721 cells through synergy of berberine and evodiamine. Phytomedicine 15: 1062-1068, 2008.

25. Gołab J, Stokłosa T, Zagozdzon R, Kaca A, Giermasz A, Pojda Z, Machaj E, Dabrowska A, Feleszko W, Lasek W, IwanOsiecka A and Jakóbisiak M: G-CSF prevents the suppression of bone marrow hematopoiesis induced by IL-12 and augments its antitumor activity in a melanoma model in mice. Ann Oncol 9 : 63-69, 1998.

26. Chou TC and Talalay P: Quantitative analysis of dose-effect relationships: the combined effects of multiple drugs or enzyme inhibitors. Adv Enzyme Regul 22: 27-55, 1984.

27. Issat T, Jakóbisiak M and Golab J: Berberine, a natural cholesterol reducing product, exerts antitumor cytostatic/cytotoxic effects independently from the mevalonate pathway. Oncol Rep 16: $1273-1276,2006$.

28. Dimitroulakos J, Nohynek D, Backway KL, Hedley DW, Yeger H, Freedman MH, Minden MD and Penn LZ: Increased sensitivity of acute myeloid leukemias to lovastatin-induced apoptosis: a potential therapeutic approach. Blood 93: 1308-1318, 1999.

29. Agarwal B, Rao CV, Bhendwal S, Ramey WR, Shirin H, Reddy BS and Holt PR: Lovastatin augments sulindac-induced apoptosis in colon cancer cells and potentiates chemopreventive effects of sulindac. Gastroenterology 117: 838-847, 1999.

30. Feleszko W, Młynarczuk I, Olszewska D, Jalili A, Grzela T, Lasek W, Hoser G, Korczak-Kowalska G and Jakóbisiak M: Lovastatin potentiates antitumor activity of doxorubicin in murine melanoma via an apoptosis-dependent mechanism. Int J Cancer 100: 111-118, 2002

31. Jakóbisiak M, Bruno S, Skierski JS and Darzynkiewicz Z: Cell cycle-specific effects of lovastatin. Proc Natl Acad Sci USA 88 3628-3632, 1991

32. Rao S, Porter DC, Chen X, Herliczek T, Lowe M and Keyomarsi K Lovastatin-mediated G1 arrest is through inhibition of the proteasome, independent of hydroxymethyl glutaryl-CoA reductase. Proc Natl Acad Sci USA 96: 7797-7802, 1999.
33. Bouterfa HL, Sattelmeyer V, Czub S, Vordermark D, Roosen K and Tonn JC: Inhibition of Ras farnesylation by lovastatin leads to down-regulation of proliferation and migration in primary cultured human glioblastoma cells. Anticancer Res 20: 2761-2771, 2000.

34. DeClue JE, Vass WC, Papageorge AG, Lowy DR and Willumsen BM: Inhibition of cell growth by lovastatin is independent of ras function. Cancer Res 51: 712-717, 1991.

35. Crick DC, Andres DA, Danesi R, Macchia M and Waechter CJ: Geranylgeraniol overcomes the block of cell proliferation by lovastatin in C6 glioma cells. J Neurochem 70: 2397-2405, 1998.

36. Rao S, Lowe M, Herliczek TW and Keyomarsi K: Lovastatin mediated G1 arrest in normal and tumor breast cells is through inhibition of CDK2 activity and redistribution of p21 and p27, independent of p53. Oncogene 17: 2393-2402, 1998.

37. Gray-Bablin J, Rao S and Keyomarsi K: Lovastatin induction of cyclin-dependent kinase inhibitors in human breast cells occurs in a cell cycle-independent fashion. Cancer Res 57: 604-669, 1997.

38. Park WH, Lee YY, Kim ES, Seol JG, Jung CW, Lee CC and Kim BK: Lovastatin-induced inhibition of HL-60 cell proliferation via cell cycle arrest and apoptosis. Anticancer Res 19: 3133-3140, 1999.

39. Oda H, Kasiske BL, O'Donnell MP and Keane WF: Effects of lovastatin on expression of cell cycle regulatory proteins in vascular smooth muscle cells. Kidney Int (Suppl) 71: S202-S205, 1999.

40. Naderi S, Blomhoff R, Myklebust J, Smeland EB, Erikstein B, Norum KR and Blomhoff HK: Lovastatin inhibits G1/S transition of normal human B-lymphocytes independent of apoptosis. Exp Cell Res 252: 144-153, 1999.

41. Feleszko W, Mlynarczuk I, Balkowiec-Iskra EZ, Czajka A, Switaj T, Stoklosa T, Giermasz A and Jakóbisiak M: Lovastatin potentiates antitumor activity and attenuates cardiotoxicity of doxorubicin in three tumor models in mice. Clin Cancer Res 6: 2044-2052, 2000.

42. Rozados VR, Hinrichsen LI, Binda MM, Gervasoni SI, Matar P, Bonfil RD and Scharovsky OG: Lovastatin enhances the antitumoral and apoptotic activity of doxorubicin in murine tumor models. Oncol Rep 19: 1205-1211, 2008.

43. Werner M, Sacher J and Hohenegger M: Mutual amplification of apoptosis by statin-induced mitochondrial stress and doxorubicin toxicity in human rhabdomyosarcoma cells. Br J Pharmacol 143: 715-724, 2004

44. Feleszko W, Zagozdzon R, Gołab J and Jakóbisiak M: Potentiated antitumour effects of cisplatin and lovastatin against MmB16 melanoma in mice. Eur J Cancer 34: 406-411, 1998.

45. Kozar K, Kaminski R, Legat M, Kopec M, Nowis D, Skierski JS, Koronkiewicz M, Jakóbisiak M and Golab J: Cerivastatin demonstrates enhanced antitumor activity against human breast cancer cell lines when used in combination with doxorubicin or cisplatin. Int J Oncol 24: 1149-1157, 2004.

46. Mantha AJ, McFee KE, Niknejad N, Goss G, Lorimer IA and Dimitroulakos J: Epidermal growth factor receptor-targeted therapy potentiates lovastatin-induced apoptosis in head and neck squamous cell carcinoma cells. J Cancer Res Clin Oncol 129: 631-641, 2003.

47. Wang W, Collie-Duguid E and Cassidy J: Cerivastatin enhances the cytotoxicity of 5-fluorouracil on chemosensitive and resistant colorectal cancer cell lines. FEBS Lett 531: 415-420, 2002.

48. Orfila L, Rodríguez M, Colman T, Hasegawa M, Merentes E and Arvelo F: Structural modification of berberine alkaloids in relation to cytotoxic activity in vitro. $\mathrm{J}$ Ethnopharmacol 71: 449-456, 2000

49. Eom KS, Hong JM, Youn MJ, So HS, Park R, Kim JM and Kim TY: Berberine induces G1 arrest and apoptosis in human glioblastoma T98G cells through mitochondrial/caspases pathway. Biol Pharm Bull 31: 558-562, 2008.

50. Piyanuch R, Sukhthankar M, Wandee G and Baek SJ: Berberine, a natural isoquinoline alkaloid, induces NAG-1 and ATF3 expression in human colorectal cancer cells. Cancer Lett 258: 230-240, 2007.

51. Meeran SM, Katiyar S and Katiyar SK: Berberine-induced apoptosis in human prostate cancer cells is initiated by reactive oxygen species generation. Toxicol Appl Pharmacol 229: 33-43, 2008.

52. Lin JP, Yang JS, Lee JH, Hsieh WT and Chung JG: Berberine induces cell cycle arrest and apoptosis in human gastric carcinoma SNU-5 cell line. World J Gastroenterol 12: 21-28, 2006. 
53. Katiyar SK, Meeran SM, Katiyar N and Akhtar S: p53 cooperates berberine-induced growth inhibition and apoptosis of non-small cell human lung cancer cells in vitro and tumor xenograft growth in vivo. Mol Carcinogenesis 48: 24-37, 2009.

54. Lin S, Tsai SC, Lee CC, Wang BW, Liou JY and Shyu KG: Berberine inhibits HIF-1alpha expression via enhanced proteolysis. Mol Pharmacol 66: 612-619, 2004.

55. Lin JP, Yang JS, Wu CC, Lin SS, Hsieh WT, Lin ML, Yu FS, Yu CS, Chen GW, Chang YH and Chung JG: Berberine induced down-regulation of matrix metalloproteinase-1, -2 and -9 in human gastric cancer cells (SNU-5) in vitro. In Vivo 22: 223-230, 2008

56. Kim S, Choi JH, Kim JB, Nam SJ, Yang JH, Kim JH and Lee JE: Berberine suppresses TNF-alpha-induced MMP-9 and cell invasion through inhibition of AP-1 activity in MDA-MB231 human breast cancer cells. Molecules 13: 2975-2985, 2008.

57. Ho YT, Yang JS, Li TC, Lin JJ, Lin JG, Lai KC, Ma CY, Wood WG and Chung JG: Berberine suppresses in vitro migration and invasion of human SCC-4 tongue squamous cancer cells through the inhibitions of FAK, IKK, NF- $\mathrm{KB}$, u-PA and MMP-2 and -9. Cancer Lett 279: 155-162, 2009.

58. Peng PL, Hsieh YS, Wang CJ, Hsu JL and Chou FP: Inhibitory effect of berberine on the invasion of human lung cancer cells via decreased productions of urokinase-plasminogen activator and matrix metalloproteinase-2. Toxicol Appl Pharmacol 214 $8-15,2006$
59. Mitani $\mathrm{N}$ and Murakami K: Inhibitory effect of berberine on the mediastinal lymph node metastasis. Cancer Lett 165: 35-42, 2001.

60. Li H, Guo L, Jie S, Liu W, Zhu J, Du W, Fan L, Wang X, Fu B and Huang S: Berberine inhibits SDF-1-induced AML cells and leukemic stem cells migration via regulation of SDF-1 level in bone marrow stromal cells. Biomed Pharmacother 62: 573-578, 2008.

61. Kong WJ, Wei J, Zuo ZY, Wang YM, Song DQ, You XF, Zhao LX, Pan HN and Jiang JD: Combination of simvastatin with berberine improves the lipid-lowering efficacy. Metabolism 57: 1029-1037, 2008.

62. Bjerre LM and LeLorier J: Do statins cause cancer? A metaanalysis of large randomized clinical trials. Am J Med 110: 716-723, 2001.

63. Dale KM, Coleman CI, Henyan NN, Kluger J and White CM: Statins and cancer risk: a meta-analysis. JAMA 295: 74-80, 2006.

64. Winiarska M, Bil J, Wilczek E, Wilczynski GM, Lekka M, Engelberts PJ, Mackus WJ, Gorska E, Bojarski L, Stoklosa T, Nowis D, Kurzaj Z, Makowski M, Glodkowska E, Issat T, Mrowka P, Lasek W, Dabrowska-Iwanicka A, Basak GW, Wasik M, Warzocha K, Sinski M, Gaciong Z, Jakobisiak M, Parren PW and Golab J: Statins impair antitumor effects of rituximab by inducing conformational changes of CD20. PLoS Med 5: e64, 2008. 